\title{
Utilizing Home Rule: The Case for Restricting Hydraulic Fracturing at the Local Level
}

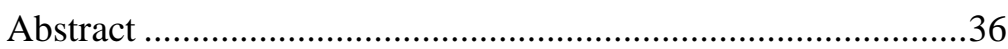

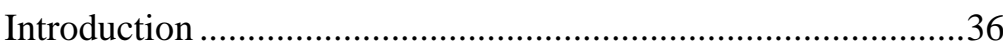

I. Hydraulic Fracturing: The Process and Its Associated

Environmental and Public Health Impacts .......................38

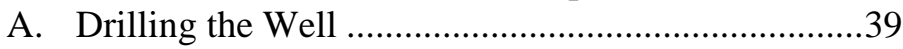

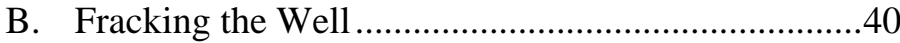

C. Disposal of Wastewater...........................................42

II. Lack of Legal Protection for Affected Landowners

Suffered as a Result of Poorly Defined Property

Rights

A. Adjoining Properties Held in Fee Simple Absolute by Two Different Owners.

B. One Property Has Severed Oil, Mineral, and Gas Rights Which Are Held in Fee Simple by a Party Other than the Surface Owner...

III. Inadequacy of the Current Hydraulic Fracturing

Regulatory Regime

A. Exemptions to Major Federal Environmental Legislation .50

B. State Regulation of Hydraulic Fracturing ................53

IV. Suggested Strategies for Municipalities ...........................57

A. Legal Precedent for the Power of Municipalities to Use Home Rule to Restrict Hydraulic Fracturing Operations

\footnotetext{
* Emory University School of Law Class of 2016. I would like to extend my sincerest thanks to Professor Frank S. Alexander for his endless insight, guidance, and encouragement in the development of this Article. And to my family and my fiancé, my pillars and my strength, for always supporting me in all of my endeavors.
} 
B. Suggested Zoning Ordinances and Land Use Laws that Will Limit the Negative Impacts of Hydraulic Fracturing upon Local Residents.....

1. Enact or Modify Local Comprehensive Plans....60

2. Enact Zoning Ordinances Increasing the Required Distance of Hydraulic Fracturing Operations from High Risk Areas

3. Ban Hydraulic Fracturing

Conclusion

\begin{abstract}
The surge of hydraulic fracturing in the United States has spawned concern over public health risks associated with the practice. Some states, such as New York, have ultimately banned hydraulic fracturing citing significant environmental and public health hazards. Nationally, debate over regulation of hydraulic fracturing has taken center stage. The current regulatory scheme is a patchwork of state regulation with minimal federal oversight that leaves many individuals at risk of health and property damages.

For individuals negatively affected by hydraulic fracturing, pursuing a cause of action may not be a viable option. Poorly defined property rights and significant evidentiary barriers often hinder individuals from the ability to purse a legal remedy for injuries suffered as a result of nearby hydraulic fracturing operations.

Using their home rule powers, municipalities may be in the best position to insulate their residents from health and property damages by restricting or banning hydraulic fracturing within their borders. This Article will analyze why hydraulic fracturing poses substantial health and property risks; why the currently regulatory regime leaves individuals vulnerable; and will suggest strategies for municipalities to restrict or ban hydraulic fracturing within their borders.
\end{abstract}

\title{
INTRODUCTION
}

The modern advent of hydraulic fracturing, or "hydrofracking," has spawned a near frenzy of oil and natural gas extraction in the United States. ${ }^{1}$ Hydrofracking of shale plays, in particular, has been heralded

1 Since 2005, more than 80,000 wells have been drilled or permitted. ELIZABETH RIDLINGTON \& JOHN RUMPLER, ENV’T AMERICA RESEARCH \& POLICY CTR., FRACKING By the Numbers: Key IMPACTS of DiRTy DRILling at the STATE AND NATIONAL 
as the golden goose of the energy sector and is estimated to have the ability to supply the United States with enough natural gas to power the country for the next 100 years. $^{2}$

Hydrofracking has also incited strong, and growing, opposition due to its environmental and public health consequences. ${ }^{3}$ Water contamination cases in Pennsylvania delivered images of residents' tap water igniting in flames due to high levels of methane. ${ }^{4}$ Another concern regarding this practice is that this technology has existed for merely sixteen years. ${ }^{5}$ Thus, the potentially negative long-term ramifications of this practice have yet to be seen. Yet, in a race to begin developing shale plays in the United States, wells being drilled number in the thousands each year. ${ }^{6}$ It is estimated that more than 15 million Americans now live within one mile of a hyrofracking well. ${ }^{7}$

The surge of hydrofracking is of particular importance because under the current legal and regulatory regime, many people bear an inequitable burden as a result of living in the vicinity of hydrofracking operations. Individuals are unreasonably impacted by hydrofracking for three primary reasons. First, the allocation of property rights disproportionately favors hydrofracking operators, and often puts private citizens directly at risk from property and health related

LEVEL at 4 (2013), http://www.environmentamerica.org/sites/environment/files/reports/EA _FrackingNumbers_scrn.pdf.

2 Ben Casselman, U.S. Gas Fields Go from Bust to Boom, WALl ST. J. (Apr. 30, 2009, 11:59 PM), http://online.wsj.com/article/SB124104549891270585.html.

3 Governor Andrew Cuomo's administration recently decided to ban high volume hydraulic fracturing in the state of New York citing “[p]otential health and environmental impacts includ[ing] drinking-water and soil contamination, and methane releases tied to climate change.” Erica Orden \& Lynn Cook, New York Moves to Ban Fracking, WALL ST. J. (Dec. 18, 2014, 12:27 AM), http://www.wsj.com/articles/new-york-gov-andrew-cuomos -administration-moves-to-ban-fracking-1418839033.

4 Sarah Hoye \& Steve Hargreaves, 'Fracking' Yields Fuel, Fear in Northeast, CNN (Sept. 3, 2010, 7:06 AM), http://www.cnn.com/2010/US/09/02/fracking/.

5 Russell Gold, When Did the Energy Industry Begin Fracking?, THE HuFFINGTON POST (May 23, 2014, 5:59 AM), http://www.huffingtonpost.com/quora/when-did-the-energy -indus_b_5019285.html (citing June 1998 as the birthdate of modern hydraulic fracturing technology).

6 See Ridlington \& Rumpler, supra note 1, at 8.

7 Matthew McFeeley, Falling Through the Cracks: Public Information and the Patchwork of Hydraulic Fracturing Disclosure Laws, 38 VT. L. REV. 849, 849 (2014); Russell Gold \& Tom McGinty, Energy Boom Puts Wells in America's Backyards: Hydraulic Fracturing Largely Driving Transformation of the Nation's Landscape, WALL ST. J. (Oct. 25, 2013, 11:00 AM), http://online.wsj.com/news/articlcs/SB1000142405270 2303672404 579149432365326 ("At least 15.3 million Americans [live] within a mile of a well that has been drilled since 2000. That is more people than live in Michigan or New York City.”). 
damages. ${ }^{8}$ Second, due to the financial and evidentiary burden of pursing a claim for damages resulting from hydrofracking, liability is extremely difficult to establish. ${ }^{9}$ Third, the current regulatory framework is minimal at the federal level and inadequate at the state level. ${ }^{10}$

As the use of hydrofracking continues to accelerate, it is imperative that individuals are insulated from unreasonably shouldering this heavy burden. To ensure protection for these individuals, municipalities ${ }^{11}$ may be able to use their home rule ${ }^{12}$ powers to implement rules that more adequately insulate their residents from the hazards of hydrofracking.

This Article analyzes the hydrofracking process and identifies the potential environmental and health consequences of each phase. Part II then examines why the allocation of property rights puts private citizens directly at risk of suffering property and health related consequences, and why pursuing a legal remedy for these injuries is extremely difficult. Finally, Parts III-IV address the inadequacy of the current regulatory regime and offers suggested strategies for municipalities to employ in restricting hydrofracking at the local level.

\section{I}

\section{Hydraulic Fracturing: THE Process AND ItS Associated ENVIRONMENTAL AND PUBLIC HEALTH IMPACTS}

Hydrofracking is a recent innovation in oil and natural gas exploration, which has revolutionized production. ${ }^{13}$ This new

8 See infra notes 67-103.

9 Id.

10 See infra notes 104-71.

11 For purposes of this Article, I intend the term "municipalities" to include cities, counties, and other local units of government. Note, however, that there may be differences between a city's home rule powers and a county's home rule powers. However, because these powers are substantially similar, I will refer to them in the collective for simplicity. See Michael R. Heim, Legal Article: Home Rule: A Primer, 74 J. KAN. B. Ass’N 26, 29 (Jan. 2005).

12 Home rule is "[a] state legislative provision or action allocating a measure of autonomy to a local government, conditional on its acceptance of certain terms.” Home Rule, BLACK's LAW DICTIONARY (10th ed. 2014).

13 See The Process of Hydraulic Fracturing, U.S. EPA, https://www.epa.gov/hydraulic fracturing/process-hydraulic-fracturing (last updated Oct. 16, 2015) [hereinafter The Process of Hydraulic Fracturing]. For an illustration of the difference between a hydrofracking well (unconventional well) and a traditional oil and gas well (conventional well), see Bernard D. Goldstein \& Jill Kriesky, Point Of View-Unconventional Natural Gas 
innovation involves using a horizontal well and a special stimulation technique to extract oil and gas resources that have previously been inaccessible. $^{14}$

The production of shale oil and gas, in particular, has become an important area of exploration for the energy industry, as significant shale reserves are estimated to exist in at least thirty-one states. ${ }^{15}$ The ability to extract shale resources through hydrofracking has allowed for rapid and expansive oil and natural gas production, even throughout states that have otherwise never had a productive oil and gas industry. ${ }^{16}$ The industry hails hydrofracking's ability to access these large reserves of oil and gas, contending that it is the key to addressing our nation's energy crisis. ${ }^{17}$ However, hydrofracking in shale plays creates significant environmental and public health consequences that must not be overlooked. ${ }^{18}$

\section{A. Drilling the Well}

The first step in the hydrofracking process is to drill a well thousands of feet, vertically, below the Earth's surface and into shale rock, where large amounts of oil and gas are trapped between small fractures. ${ }^{19}$ The well is then drilled horizontally, thousands of feet, following the natural fractures of the shale rock. ${ }^{20}$

Properly insulating the well is essential because of the risk of groundwater contamination. ${ }^{21}$ Where hydrofracking wells are deficient, there is a potential for methane gas to escape and contaminate

Drilling, WORLD INFO. TRANSFER (Jan. 17, 2012), http://worldinfo.org/2012/01/point-of -view-unconventional-natural-gas-drilling/.

14 See The Process of Hydraulic Fracturing, supra note 13.

15 Nathan Richardson et aL., REs. For The Future, The State of State Shale GAS REGULATION 1 (2013).

16 See The Process of Hydraulic Fracturing, supra note 13.

17 Casselman, supra note 2.

18 See infra notes 19-66.

19 An Exploration of Natural Gas Drilling and Development in the Marcellus Shale, EXPLORE SHALE, http://exploreshale.org/ (last updated Aug. 2014) [hereinafter EXPLORE SHALE] (see illustration depicting a typical fracking well in the Marcellus Shale).

20 Id. (noting that “[a] typical Marcellus Shale well is drilled 5,000 to 9,000 feet vertically and up to 10,000 feet horizontally").

21 See, e.g., Hannah Wiseman, Untested Waters: The Rise of Hydraulic Fracturing in Oil and Gas Production and the Need to Revisit Regulation, 20 FORDHAM ENVTL. L. REV. 115 (2009). 
nearby groundwater. ${ }^{22}$ Multiple cases of groundwater contamination in Pennsylvania have resulted from cement failure of hydrofracking wells. In Pennsylvania, in the first eight months of 2011, sixty-five wells were cited for loss of integrity. ${ }^{23}$ In Dimock, Pennsylvania, of forty-three wells drilled in a nine-mile square radius during the course of one year, thirteen became defective. ${ }^{24}$ Subsequently, fourteen homes in Dimock suffered contaminated groundwater and drinking water supplies. ${ }^{25}$ The cause of this incident was linked to an aquifer that had been contaminated by nearby hydrofracking operations conducted by Cabot Oil and Gas Corporation. ${ }^{26}$ The Pennsylvania Department of Environmental Protection fined Cabot Oil and Gas and ordered them to plug three wells that were thought to be the source of contamination. ${ }^{27}$

\section{B. Fracking the Well}

The second phase of the hydrofracking process is fracking the well. ${ }^{28}$ During this phase, large quantities of "fracturing fluid" are pumped into the well at a high pressure in order to create horizontal fractures deep within shale rock layers. ${ }^{29}$ Fracturing fluid, or "frac fluid," is a combination of "water, proppant and chemical additives that open and enlarge fractures within the rock formation." 30

The use of frac fluid produces a number of environmental and public health concerns. First, fracking a well requires large quantities of

22 See Anthony R. Ingraffea et al., Assessment and Risk Analysis of Casing and Cement Impairment in Oil and Gas Wells in Pennsylvania, 2000-2012, 111 PROC. NAT'L ACAD. SCI. 10955 (2014); see also Comments on Draft SGEIS, ANTHONY R. INGRAFFEA ET AL., SOME SCIENTIFIC FAILINGS WITH THE DRAFT SUPPLEMENTAL GENERIC ENVIRONMENTAL STATEMENT AND PROPOSED REgULATIONS: COMMENTS AND RECOMMENDATIONS 7 (Jan. 8, 2012), http://www.psehealthyenergy.org/data/SGEIS_Scientific_Failings_Ingraffea_Jan _20121.pdf [hereinafter INGRAFFEA COMMENTS ON DRAFT SGEIS].

23 INGRAFFEA COMMENTS ON DRAFT SGEIS, supra note 22, at 7.

24 See Pennsylvania DEP Orders Dimock Gas Wells Plugged, Assesses \$240,000 Fine, PA. DEP'T. ENVTL. PROT. (Apr. 15, 2010, 12:07 PM), http://hydrofracking.virginiajournal .org/?p=80.

25 Id.

26 Cement failure and well casing failure was cited as the cause of the contamination. Id.

27 Id.

28 The Process of Hydraulic Fracturing, supra note 13.

29 Id. For a useful pictorial, see Hydraulic Fracturing: The Process, FracFocus (07/20/2010), http://fracfocus.org/hydraulic-fracturing-how-it-works/hydraulic-fracturing -process.

30 The Process of Hydraulic Fracturing, supra note 13. 
water. ${ }^{31}$ Each time a well is fractured it may require between two and ten million gallons of water. ${ }^{32}$ With nearly 82,000 wells already in operation nationwide, the demand for water is enormous. ${ }^{33}$ The sheer volume of water needed creates important water consumption concerns, particularly during times of severe drought.

The second ingredient, proppant, sometimes referred to as "frac sand," is a combination of "sand, ceramic pellets or other small incompressible particles" used to hold open these newly created fractures. ${ }^{34}$ This process allows the natural gas to flow through the fractures. ${ }^{35}$ Each well may require more than one thousand tons of frac sand. ${ }^{36}$ In 2012, the Occupational Safety and Health Administration released a report citing field studies indicating that "workers may be exposed to dust with high levels of respirable crystalline silica . . . during hydraulic fracturing." ${ }^{\text {"37 }}$ Breathing in silica is problematic, as it can cause silicosis, "a lung disease where lung tissue around trapped silica particles reacts, causing inflammation and scarring and reducing the lungs' ability to take in oxygen." 38 Breathing in silica has also been linked to lung cancer and "other diseases, such as tuberculosis, chronic obstructive pulmonary disease, and kidney and autoimmune disease."39

The final components of frac fluid are chemical additives and friction-reducing compounds. ${ }^{40}$ These additives are required in the frac

31 Hydraulic Fracturing 101, EARTHWORKS, http://www.earthworksaction.org/issues /detail/hydraulic_fracturing_101 (last visited Nov. 22, 2015).

32 Id.

33 Five years ago, the United States Environmental Protection Agency estimated that up to 140 billions of gallons of water each year were required for 35,000 wells. Id. (citing U.S. ENVTL. PRot. AGENCY, DRAFT Plan to STUDY THE POTENTIAL IMPACTS OF HydRAULIC FRACTURING ON DRINKING WATER RESOURCES 19 (Feb. 7, 2011)).

34 The Process of Hydraulic Fracturing, supra note 13.

35 Id.

36 See What is Frack Sand?, GEOLOGY.COM, http://geology.com/articles/frac-sand/ (last visited Nov. 22, 2015). In total, each shale gas well may require more than four million pounds of proppant. Hydraulic Fracturing 101, supra note 31.

37 OCCUPATIONAL SAFETY AND HEALTh ADMin., WORKER EXPOSURE TO SiliCA DURING HYDRAULIC FRACTURING 1 (2012), https://www.osha.gov/dts/hazardalerts /hydraulic_frac_hazard_alert.pdf. Workers are exposed to silica through “[t]ransporting, moving, and refilling silica sand into and through sand movers, along transfer belts, and into blender hoppers ... . [which] release[s] dusts containing silica into the air. Workers can be exposed if they breathe the dust into their lungs.” Id.

38 Id. at 3-4.

39 Id. at 4.

40 What Chemicals Are Used, FRAC FOCUS, http://fracfocus.org/chemical-use/what -chemicals-are-used (last visited Oct. 12, 2014). 
fluid because water alone is not slippery enough to travel thousands of feet below the Earth's surface at a speed and pressure high enough to fracture shale rock. ${ }^{41}$ Thus, energy companies introduce chemicals and other additives to create what is referred to as "slick water." 42 Fracking formulas vary from company to company and these chemical compositions are often not subject to public disclosure laws. ${ }^{43}$ Of the states that conduct hydrofracking operations, about one-third have no hydraulic fracturing chemical disclosure requirements. ${ }^{44}$ Even in the states that do have disclosure rules, the rules are often weak. ${ }^{45}$ Some states even allow companies to avoid disclosure to emergency medical responders who may need the information to treat affected victims at the scene of an accident, and to nearby landowners who may wish to receive notice as a result of proximity to the worksite. ${ }^{46}$ Due to nonexistent or weak disclosure rules, there is limited information on exactly what chemicals are used in frac fluid. ${ }^{47}$ What is known, however, is that at least 600 different chemicals are used ${ }^{48}$ and many formulas include known carcinogens and toxins such as lead, uranium, mercury, ethylene glycol, radium, methanol, hydrochloric acid, and formaldehyde. ${ }^{49}$ Thus, in the event of a surface spill, this chemicallaced fluid may contaminate nearby fields and water sources. ${ }^{50}$

\section{Disposal of Wastewater}

Disposal of used frac fluid also creates environmental and public health hazards. After the frac fluid is pumped through the well, between

41 Luke Geiver, The Slickwater Story, THE BAKKEN MAG. (July 14, 2014), http://the bakken.com/articles/711/the-slickwater-story.

$42 \mathrm{Id}$.

43 See McFeeley, supra note 7, at 850.

44 Id.

$45 \mathrm{Id}$.

$46 I d$.

47 See id.

48 Health Effects Spreadsheet and Summary: Multistate Spreadsheet, THE ENDOCRINE DISRUPTION EXCHANGE (Mar. 29, 2011), http://endocrinedisruption.org/chemicals-in -natural-gas-operations/chemicals (click on link to "Spreadsheet of products, chemicals and their health effects (Excel)").

49 What Chemicals Are Used, supra note 40. The information that we do have available on chemical components of frac fluid has been obtained through required or voluntary disclosures. See About Us, FRAC FOCUS, http://fracfocus.org/welcome (last visited Nov. 22, 2015).

50 EXPLORE SHALE, supra note 19 (click on "Can water become contaminated by Marcellus Shale drilling?”). 
$70 \%$ and $90 \%$ will become absorbed by shale rock. ${ }^{51}$ The remaining $10 \%$ to $30 \%$ returns to the surface and must be disposed of or recycled. ${ }^{52}$

Companies may elect to treat the wastewater, allowing the company to reuse it for future fracturing jobs at the well site. ${ }^{53}$ However, even recycling has its limits, and at some point it may no longer be economically or technologically feasible to recycle the wastewater. ${ }^{54}$ At this junction, companies must choose between one of several ways to dispose of the wastewater. ${ }^{55}$

The first method of disposal is underground injection. ${ }^{56}$ This procedure creates a risk of groundwater contamination and has also been linked to an increase in earthquakes. ${ }^{57}$

A second method of disposal is to send the wastewater to be processed at a wastewater treatment facility. ${ }^{58}$ The problem with this

51 See id. (click on "What happens to the water after it has been used for fracking?”).

52 Id.; see Earthworks et al., New Fracking Report Finds High Levels of Water Consumption and Waste Generation, EARTHWORKS (Oct. 30, 2013), http://www.earth worksaction.org/media/detail/new_fracking_report_finds_high_levels_of_water_consump tion_and_waste_genera\#.

53 EXPLORE SHALE, supra note 19 (click on "What happens to the water after it has been used for fracking?”) (noting that the wastewater is usually treated on site).

54 See Pam Boschee, Produced and Flowback Water Recycling and Reuse: Economics, Limitations, and Technology, OIL AND GAS FACILITIES, Feb. 2014, at 16, http://www. halliburton.com/public/multichem/contents/Papers_and_Articles/web/Feb-2014-Oil-Gas -Facilities-Article.pdf. Because the decision of whether to recycle or dispose of wastewater is made with costs in mind, companies may elect to dispose of waste water even when recycling would be more environmentally sound. REBECCA HAMMER \& JEANNE VANBriesen, Nat'l Res. Def. Council, In Fracking's WaKe: NeW Rules aRe NEEDED TO PROTECT OUR HEALTH AND ENVIRONMENT FROM CONTAMINATED WASTEWATER 91 (2012), http://www.nrdc.org/energy/files/Fracking-Wastewater-Full Report.pdf ("When the benefits of recycling and reuse [of wastewater] outweigh [the] disadvantages, states should encourage or require natural gas operators to reuse wastewater for additional hydraulic fracturing.”).

55 See BoscHEE, supra note 54.

56 With underground injection, the wastewater is essentially injected back into the ground through a deep well. See The Process of Hydraulic Fracturing, supra note 13; Basic Information about Injection Wells, U.S. EPA, http://water.epa.gov/type/groundwater/uic /basicinformation.cfm (last visited Nov. 22, 2015).

57 See HAMMER \& VANBRIESEN, supra note 54, at 6; Patrick J. Kiger, Scientists Warn of Quake Risk from Fracking Operations, NAT'L GEOGRAPHIC (May 2, 2014), http://news .nationalgeographic.com/news/energy/2014/05/140502-scientists-warn-of-quake-risk-from -fracking-operations/.

58 The Process of Hydraulic Fracturing, supra note 13. In the past, drillers in the Marcellus region were sending wastewater to public owned treatment works ("POTWs") for treatment. This proved to be disastrous, as the wastewater produced from fracking contained 
procedure is that traditional wastewater treatment facilities are not equipped to process the many heavy metals, toxic chemicals, and radioactive substances that are present in hydrofracking wastewater. ${ }^{59}$ Even industrial wastewater treatment facilities, which process toxic waste more effectively than traditional facilities, have proven inadequate. $^{60}$ Consequently, contamination of water sources, particularly drinking water, is a major concern raised by using the treatment method. ${ }^{61}$

The third method of disposal is through evaporation using on-site impoundments (open-air pits). ${ }^{62}$ Waste fluid is stored in impoundments and left to evaporate. ${ }^{63}$ This creates land, water, and air contamination concerns. ${ }^{64}$ Accidental spills or mismanagement can result in the contamination of nearby groundwater and soils. ${ }^{65}$ Evaporation of wastewater also creates hazardous air pollution by releasing harmful, volatile organic compounds into the atmosphere. ${ }^{66}$

\section{II}

\section{LACK Of LEgAL PRotection FOR AFFECTED LANDOWNERS Suffered As A Result of POORLy Defined Property Rights}

Hydrofracking has the potential to impose significant damages upon individuals located within the close proximity of hydrofracking operations. These damages may include adverse health effects from air and water contamination, surface and subsurface property damage from drilling, and declines in property values brought on by sheer

high levels of dissolved solids (primarily salts) that POTWs were incapable removing. These salts were subsequently discharged into receiving water bodies. As a result, Pennsylvania has either required facilities to reject fracking wastewater that has not been pretreated or to stop accepting fracking wastewater all together. HAMMER \& VANBRIESEN, supra note 54, at 4 .

59 'Fracking' Wastewater that is Treated for Drinking Produces Potentially Harmful Compounds, AM. CHEM. SOC’y (Sept. 24, 2014, 13:38:34 EDT), http://www.acs.org /content/acs/en/pressroom/presspacs/2014/acs-presspac-september-24-2014/fracking -wastewater-that-is-treated-for-drinking-produces-potentially-harmful-compounds.html (noting that this process could be putting drinking water supplies at risk).

60 See HAMMER \& VANBRIESEN, supra note 54, at 4.

$61 \mathrm{Id}$.

62 Id. at 57.

$63 \mathrm{Id}$.

64 Id.

65 Id.

66 Id. at 92 (concluding that "states should not allow the storage or disposal of shale gas wastewater in open impoundments," and "if impoundments are not prohibited, they should be more strictly regulated”). 
proximity to hydrofracking operations. ${ }^{67}$ Damages are of particular importance because it is estimated that more than 15 million Americans now live within one mile of a hydrofracking well. ${ }^{68}$

Affected individuals can file a cause of action seeking a remedy for the injury suffered, however, each potential cause of action fails to fully protect individuals. To illustrate the pitfalls of this system, each cause of action will be analyzed as it occurs under two contexts: (1) two adjoining properties are held in fee simple absolute by two different owners; and (2) one property with severed oil, mineral, and gas rights which are held in fee simple by a party other than the surface owner.

\section{A. Adjoining Properties Held in Fee Simple Absolute by Two Different Owners}

Parcel 1 and Parcel 2 are adjoining properties. Owner A owns Parcel 1 in fee simple absolute; owner B owns Parcel 2 in fee simple absolute. Owner A is a residential homeowner. Owner B is an energy company. ${ }^{69}$ In this context, damages result from neighboring, or living in close proximity to hydrofracking operations. The two most common causes of action resulting from this context are nuisance and trespass. ${ }^{70}$

\footnotetext{
67 Researchers at the University of Denver conducted a study of 550 individuals living in Texas, Alabama, and Florida, finding that a majority of people said they would decline to buy a home near a drilling site and others would be willing to buy but would reduce their offers by up to 25\%. Ron Throupe et al., A Review of Hydro "Fracking" and its Potential Effects on Real Estate, 21 J. REAL EST. LITERATURE 205, 224 n.29 (2013). A study of rural residential property values in Alberta, Canada, found that the presence of oil and gas facilities within two-and-a-half miles of rural residential properties reduced property values between $4 \%$ and $8 \%$. P. Boxall et al., The Impact of Oil and Natural Gas Facilities on Rural Residential Property Values: A Spatial Hedonic Analysis, ResOuRCES \& ENERGY ECONOMICS 27, 248-69. Similarly, a study of residential property values in Washington County, Pennsylvania, determined a $24 \%$ decrease in property values for homes that depend on groundwater and are located within 2000 meters of a fracking well. Lucija Muehlenbachs et al., Shale Gas Development and Property Values: Differences Across Drinking Water Sources 29-30 (Nat'l Bureau of Econ. Research, Working Paper No. 18390, 2012), http://www.nber.org/papers/w18390.pdf.

68 McFeeley, supra note 7, at 850; Gold \& McGinty, supra note 7 ("At least 15.3 million Americans lived within a mile of a well that has been drilled since 2000. That is more people than live in Michigan or New York City.”).

69 This scenario would produce the same result even if Parcel 2 were merely leased to an energy company.

70 Hannah Wiseman, Beyond Coastal Oil v. Garza: Nuisance and Trespass in Hydraulic Fracturing Litigation, 57 THE ADVOC. (TEXAS) 8, 8 (2011).
} 
A private nuisance is "a nontrespassory invasion of another's interest in the private use and enjoyment of land." "11 Affected individuals with groundwater contamination claims would file their case under a claim of private nuisance. ${ }^{72}$ One of the most serious impediments to succeeding under this type of claim is the difficulty in proving causation. ${ }^{73}$ Although there is array of scientific and anecdotal evidence that links hydrofracking to water contamination, the reality is that proving legal causation can often be difficult. ${ }^{74}$ First, to prove that water quality has been degraded as a result of hydrofracking, baseline testing is often necessary to establish the quality of the groundwater prior to onset of hydrofracking. ${ }^{75}$ Then, upon suspicion of contamination, another test and analysis of the water must be conducted. ${ }^{76}$ Assuming that testing confirms that the groundwater is in fact contaminated, it may also be hard to pinpoint the exact causation link, as natural causes or multiple actors in the area may all be responsible for the resulting contamination. ${ }^{77}$

71 RESTATEMENT (SECOND) OF TORTS § 821D (1979). To prove private nuisance, a plaintiff must show that the defendant's conduct is “a legal cause of an invasion of another's interest in the private use and enjoyment of land, and the invasion is either (a) intentional and unreasonable, or (b) unintentional and otherwise actionable under the rules controlling liability for negligent or reckless conduct, or for abnormally dangerous conditions or activities.” RESTATEMENT (SECOND) OF TORTS § 822 (1979).

72 See RESTATEMENT (SECOND) OF TORTS § 832 (1979).

73 Potential plaintiffs may need to provide documentary and physical evidence, and expert reports, tests, and testimony. Rachel M. Kane, Annotation, Cause of Action Based on Nuisance for Personal and Property Injury Related to Hydraulic Fracturing Method of Gas Drilling, 55 CAUSES OF ACTION 2d 1, § 22 (2015).

74 Keith B. Hall, Hydraulic Fracturing Contamination Claims: Problems of Proof, 74 OHIO STATE L.J. FURTHERMORE 71, 71-72 (2013).

$75 \mathrm{Id}$. at 76 . Some states have recognized this issue and have enacted regulations either requiring or encouraging drillers to conduct baseline testing prior to drilling or fracturing an oil or gas well. Id. For example, Colorado requires initial baseline testing before a well can be drilled, and requires additional samples at varying intervals following well completion. Id. at 76-77 (citing 2 COLO. CODE REGS. § 404-1:609 et seq. (2012)). Alternatively, in Pennsylvania, a state statute creates a rebuttable presumption that if contamination of a well occurs within twelve months after hydrofracking, it is presumed that the contamination resulted from oil and gas operations. Id. at 77-78 (citing 58 PA. CONS. STAT. ANN. § 3218(c)(2) (West 2012)). Thus, there is not a requirement for baseline testing of the well, but the statute encourages oil and gas operations to perform the baseline testing in order to rebut the presumption that hydrofracking is the cause of contamination.

76 Id. at 74.

77 Id. at $74-75$. 
Another common claim that arises as a result of hydrofracking is subsurface trespass ${ }^{78}$ by neighboring fracking operations. The most notable subsurface trespass case regarding hydrofracking is Coastal Oil v. Garza. ${ }^{79}$ In Garza, a neighboring mineral owner filed suit claiming subsurface trespass damages against Coastal Oil after its hydrofracking operations drained the owner's natural gas reserves. ${ }^{80}$ The court used the common law rule of capture ${ }^{81}$ to support a finding in favor of Coastal Oil. ${ }^{82}$ The result leaves neighboring mineral owners with no cause of action for the drainage of their resources. ${ }^{83}$ The court's decision is not surprising considering the long-standing legal principle of the rule of capture. However, hydrofracking introduces a new question about subsurface trespass, unrelated to the actual drainage of resources: could the actual fractures themselves qualify as a trespass? The court in Garza did not reach this question, but seems to suggest the contrary. ${ }^{84}$

Neighboring landowners with subsurface pollution claims may have a stronger case for subsurface trespass. ${ }^{85}$ In FPL Farming $v$. Environmental Processing, plaintiffs alleged subsurface pollution from

78 The essential element of trespass is an invasion of property in which the plaintiff has a possessory or ownership interest. Eric M. Larson, Annotation, Cause of Action Against Neighboring Landowner for Trespass, 61 CAUSES OF ACTION 2d 467, § 6 (2015) (citing Gregory Village Partners, L.P. v. Chevron U.S.A., Inc., 805 F. Supp. 2d 888 (N.D. Cal. 2011)). In actions for subsurface trespass, the cause of action typically arises as a result of the drainage of natural resources to which the plaintiff has a possessory interest. See Owen L. Anderson, Subsurface "Trespass": A Man's Subsurface is Not His Castle, 49 WASHBURN L.J. 247, 258 (2010).

79 Coastal Oil \& Gas Corp. v. Garza Energy Trust, 268 S.W.3d 1 (Tex. 2008); Wiseman, supra note 70.

80 Garza, 268 S.W.3d at 5-8.

81 The rule of capture "gives a mineral rights owner title to the oil and gas produced from a lawful well bottomed on the property, even if the oil and gas flowed to the well from beneath another owner's tract.” Id. at 13.

82 Id. at 14.

83 Wiseman, supra note 70, at 9. Other courts have not followed this decision. See, e.g., Kerr McGee Corp. v. ANR Production Co., 893 P.2d 698, 701 (Wyo. 1995) (finding an actionable trespass under where drainage of natural gas resources resulted from neighboring hydraulic fracturing operations).

84 Garza, 268 S.W.3d at 11-12 (stating that "[w]e need not decide the broader issue" of whether "subsurface fracing can give rise to an action for trespass"); Wiseman, supra note 70 , at 9 (concluding that "it may be difficult for neighboring mineral lessors-who in Texas must prove 'actual, permanent harm to the property' to maintain a trespass action - to show that fractures create such harm. Fractures far beneath the surface may not cause any harm other than draining the oil or gas.”).

85 Wiseman, supra note 70 , at 9. 
hydrofracking wastewater had migrated from a nearby injection well. ${ }^{86}$ The court did not squarely decide whether this action constituted a trespass $^{87}$ but seemed to leave the door open to the possibility. ${ }^{88}$ The court distinguished Garza, noting that Garza dealt with the extraction of minerals and thus, the rule of capture applied. Whereas in the instant case, the trespass was caused by wastewater injection; thus, the rule of capture does not apply. ${ }^{89}$ While both cases seem to leave open a possibility for recovery, there is still a great deal of uncertainty in this area.

\section{B. One Property Has Severed Oil, Mineral, and Gas Rights Which Are Held in Fee Simple by a Party Other than the Surface Owner}

In this context, there is one parcel in which Owner A, a residential owner, owns the surface rights and Owner B, an energy company, owns the mineral rights. The estate in this case is deemed a "severed estate."90 In general, the "mineral owner" reserves an interest in "the extraction of substances found on or under the ground,"91 and the "surface owner" retains "the residuary rights or ownership in the land." 92

When the estate is severed, the interests between the parties may conflict, particularly where the mineral estate owner desires to extract the minerals from the subsurface estate while the surface owner is in physical possession of the surface estate. The problem arises because in many states the mineral estate is the dominant estate and the surface estate is the servient estate. ${ }^{93}$ In general, the mineral owner has the right to "reasonable use" of the surface in order to develop the land. ${ }^{94}$ Courts

86 FPL Farming Ltd. v. Environmental Processing Systems, 351 S.W.3d 306, 307 (Tex. 2011).

87 The court's holding was that, "a permit granted by an agency does not act to immunize the permit holder from civil tort liability." Id. at 310.

88 See Wiseman, supra note 70, at 10.

89 FPL Farming Ltd., 351 S.W.3d at 314.

90 See OWEn L. ANDERSON ET AL., HEMingway OIL AND Gas LaW AND TAXATION 1 (4th ed. 2004).

$91 \mathrm{Id}$.

92 Id.

93 Michael Goldman, A Survey of Typical Claims and Key Defenses Asserted in Recent Hydraulic Fracturing Litigation, 1 TEX. A\&M L. REV. 305, 320-21 (2013).

94 Jason P. Webb, Pennsylvania \& Coalbed Methane: Reviving the Traditional Willingness to Protect Surface Owners, 27 TEMP. J. SCI. TECH. \& ENVTL. L. 35, 40 (2008). See also Douglas H. Gross, Annotation, What Constitutes Reasonably Necessary Use of the Surface of the Leasehold by a Mineral Owner, Lessee, or Driller Under an Oil and Gas Lease or Drilling Contract, 53 A.L.R.3d 16 (1973) (updated weekly) (last visited Nov. 24, 2015). 
have broadly defined what is "reasonable" in the course of mineral extraction. ${ }^{95}$

Many residential homebuyers do not use the assistance of legal counsel in purchasing real estate. ${ }^{96}$ As a result, when buying a severed estate, the average homebuyer may not be aware of their rights or understand the implications of their purchase. To exacerbate the issue, many states do not require sellers to disclose whether the buyer is receiving the right to the entire estate or merely the surface estate. The duty is on the buyer to inquire as to this matter. ${ }^{97}$

With the expansion of natural gas exploration, sellers are more often retaining the rights to the mineral estate and conveying only the rights to the surface. ${ }^{98}$ This is particularly true with real estate developers who wish to retain the minerals rights to an entire subdivision, creating an efficient and desirable leasing arrangement to oil and gas companies. ${ }^{99}$

The mortgage industry has begun to recognize the risk of lending to individuals who live within close proximity to a hydrofracking well or do not have legal title to the mineral estate beneath their land. ${ }^{100}$ Many lenders have begun to decline to originate mortgages on land where a third party holds oil and gas rights. ${ }^{101}$ Even large, national scale lenders, such as Wells Fargo, have admitted to approaching home loans for properties that have active gas-drilling leases attached with a high degree of caution. ${ }^{102}$ Moreover, insurance companies typically refuse to cover damages created as a result of oil and gas exploration on the property. ${ }^{103}$

95 John S. Lowe, The Easement of the Mineral Estate for Surface Use: An Analysis of Its Rationale, Status, and Prospects, 39 RocKY MTN. MiN. L. INST. 4, § 4.03 (1993).

96 Michelle Conlin \& Brian Grow, Special Report-U.S. Builders Hoard Mineral Rights Under New Homes, REUTERS (Oct. 9, 2013), http://www.reuters.com/article/2013/10/09 /usa-fracking-rights-idUSL1N0HT1KS20131009.

97 Id.

$98 \mathrm{Id}$.

99 Id.

100 See Elisabeth N. Radow, Homeowners and Gas Drilling Leases: Boon or Bust?, 83 N.Y. ST. B.J. 9 (Nov./Dec. 2011).

101 David Morrison, SECU Pulls Back From Financing Fracking Property, CREDITUNIONTIMES (Nov. 14, 2013), http://www.cutimes.com/2013/11/14/secu-pulls -back-from-financing-fracking-property; Andy Peters, Fracking Boom Gives Banks Mortgage Headaches, AMERICAN BANKER (Nov. 12, 2013), http://www.americanbanker .com/issues/178_218/fracking-boom-gives-banks-mortgage-headaches-1063561-1.html ?pg=2.

102 Radow, supra note 100, at 10, 17.

103 Id. at 10, 19. 
The combination of these issues leaves many residential homeowners in a no-win situation. An individual may purchase real property without knowledge of the existence of a severed estate; this individual will then be subjected to a number of nuisances and potential damages while oil and gas companies develop the surface estate to explore for and extract natural resources beneath the surface; when damages arise, insurance companies will not cover the cost of repairs. The lack of protection for potentially affected individuals reinforces the need for municipalities to enact zoning ordinances that may better insulate individuals from this harm.

\section{III \\ INADEQUACY OF THE CURRENT HYDRAULIC FRACTURING REGULATORY REGIME}

To protect their residents, local governments need to act because hydrofracking regulation is largely deficient at both the federal and state level. Hydrofracking operations are widely exempt from federal legislation leaving the states to fill these gaps. Because hydrofracking technology allows access to unconventional sources of oil and natural gas, production has sprung up in states that generally lack experience in regulating oil and gas operations. The result is a system that leaves individuals highly vulnerable to the potential negative consequences of hydrofracking.

\section{A. Exemptions to Major Federal Environmental Legislation}

Due to concerns of ground water contamination, the most notable exemption in federal legislation is hydrofracking's exemption under the Safe Drinking Water Act ("SDWA"). ${ }^{104}$ The primary goal of the SDWA is to ensure the safety of public drinking water. ${ }^{105}$ To achieve

\footnotetext{
104 See Rebecca Jo Reser \& David T. Ritter, State and Federal Legislation and Regulation of Hydraulic Fracturing, 57 THE ADVOC. (TEXAS) 31, 32 (2011) (noting that the exclusion for hydraulic fracturing under the Safe Drinking Water Act "has received growing scrutiny as public fears over underground water contamination have grown”); Safe Drinking Water Act, 42 U.S.C. § 300h (2012). Drinking water comes from either ground water or surface water. Ground water is generally derived from underground aquifers whereas surface water is generally derived from rivers, lakes, and above ground reservoirs. Although more people drink from surface water sources than ground water sources, smaller water systems still tend to utilize ground water sources. OfFICE OF WATER, U.S. ENVTL. PROT. AgENCY, WATER ON TAP, WhAT You NEED TO KNOW 7 (Dec. 2009), http://water.epa.gov /drink/guide/upload/book_waterontap_full.pdf.

105 See 42 U.S.C. §§ 300g-300g-9; Reser \& Ritter, supra note 104.
} 
this goal, the SDWA regulates "public water systems"106 through "regulations concerning maximum contaminant levels in drinking water, as well as monitoring and reporting requirements."107 Additionally, the SDWA "establishes minimum requirements for state Underground Injection Control (“UIC”) programs, including 'inspection, monitoring, recordkeeping, and reporting requirements." "108

In 1994, the Legal Environmental Assistance Foundation ("LEAF”) petitioned the EPA to withdraw Alabama's UIC program, alleging that it was deficient because it did not regulate hydraulic fracturing activities, as required by the SDWA. ${ }^{109}$ EPA denied the petition, arguing that the SDWA's definition of "underground injection" did not include hydraulic fracturing activities. ${ }^{110}$ The Eleventh Circuit looked to the statutory definition of "underground injection." 111 The statute reads, "[t]he term 'underground injection' means the subsurface emplacement of fluids by well injection." 112 EPA contended that because the statute did not define "well injection," EPA had the authority to interpret its meaning and implement their own definition. ${ }^{113}$ The Eleventh Circuit disagreed, holding that EPA's interpretation was not consistent with the statute. ${ }^{114}$ The court remanded for further proceedings consistent with hydraulic fracturing being regulated under the SDWA. ${ }^{115}$

Ultimately, this litigation victory was short-lived. In 2005, Congress passed the Energy Policy Act which amended the SDWA's definition of "underground injection," to specifically exclude "the underground injection of fluids or propping agents (other than diesel fuels) pursuant to hydraulic fracturing operations." ${ }^{116}$ This amendment provided absolute clarification that Congress did not intend for hydraulic

\footnotetext{
10642 U.S.C. § 300g.

107 Reser \& Ritter, supra note 104 (citing 42 U.S.C. §§ 300g-300g-9).

108 Reser \& Ritter, supra note 104 (citing 42 U.S.C. § 300h(b)(1)(c)).

109 See Legal Environmental Assistance Foundation, Inc. v. U.S. EPA, 118 F.3d 1467, 1471 (11th Cir. 1997).

110 See id.

111 Id. at 1474.

11242 U.S.C. § 300h(d)(1).

113 Legal Environmental Assistance Foundation, 118 F.3d at 1474.

114 Id. at 1478.

115 Id.; Terry W. Roberson, Environmental Concerns of Hydraulically Fracturing a Natural Gas Well, 32 UTAH ENVTL. L. REV. 67, 79 (2012).

11642 U.S.C. $\S 300 \mathrm{~h}(\mathrm{~d})(1)(B)(i i)$.
} 
fracturing operations (other than those using diesel fuels) to fall under the SDWA's definition of "underground injection."

To date, environmental groups and concerned individuals have advocated, unsuccessfully, to repeal this exemption. ${ }^{117}$ Three times, legislators attempted to pass what is known as "the Fracturing Responsibility and Awareness of Chemicals Act" (otherwise known as the "FRAC Act"). The act called for an amendment to the SDWA that would remove the exemption for hydraulic fracturing created under the Energy Policy Act. ${ }^{118}$ When it was originally introduced in June 2009, Congress did not take any action. ${ }^{119}$ It was then reintroduced in March 2011 and June 2013 to the same demise. ${ }^{120}$ For the fourth time, in March 2015, legislators reintroduced the FRAC Act. ${ }^{121}$ The likelihood that Congress will ultimately pass the act does not appear to be favorable. ${ }^{122}$

Hydrofracking is also exempt under the Resource Conservation and Recovery Act ("RCRA"). ${ }^{123}$ RCRA was enacted to "promote the protection of health and the environment and to conserve valuable material and energy resources." ${ }^{24}$ Essentially, RCRA gives the EPA authority to regulate hazardous solid waste. ${ }^{125}$ Drilling fluids, produced waters, and other wastes associated with oil and natural gas exploration, development, or production, are specifically exempted under RCRA. ${ }^{126}$ For a waste to be designated as hazardous it must meet any one of three criteria: (1) A waste may exhibit "hazardous waste

117 Reser \& Ritter, supra note 104, at 33.

118 Introduced concurrently as "Fracturing Responsibility and Awareness of Chemicals Act,” H.R. 2766 (111th), S. 1215 (111th) (hereinafter “FRAC Act”).

119 H.R. 2766 (111 $\left.{ }^{\text {th }}\right)$ : FRAC Act, GOVTRACK.US, https://www.govtrack.us/congress /bills/111/hr2766 (last visited Nov. 26, 2015); S. 1215 (111 th $)$ : FRAC Act, GOVTRACK.US, https://www.govtrack.us/congress/bills/111/s1215 (last visited Nov. 8, 2015).

120 H.R. 1084 (112 $\left.{ }^{\text {th }}\right)$ : FRAC Act, GOVTRACK.US, https://www.govtrack.us/congress /bills/112/hr1084 (last visited Nov. 26, 2015); S. 587 (112 $\left.{ }^{\text {th }}\right)$ : FRAC Act, GOvTRACK.US, https://www.govtrack.us/congress/bills/112/s587 (last visited Nov. 8, 2015); H.R. 1921 $\left(113^{\text {th }}\right)$ : FRAC Act, GOVTRACK.US, https://www.govtrack.us/congress/bills/113/hr1921 (last visited Nov. 8, 2015); S. 1135 (113 $\left.{ }^{\text {th }}\right)$ : FRAC Act, GOVTRACK.US, https://www.gov track.us/congress/bills/113/s1135 (last visited Nov. 8, 2015).

121 H.R. 1482 (114th); S. 785 (114th).

122 H.R. 1482 (114 $\left.{ }^{\text {th }}\right)$ : FRAC Act, GOVTRACK.US, https://www.govtrack.us/congress /bills/114/hr1482 (last visited Nov. 26, 2015) (indicating a 1\% chance of H.R. 1482 being enacted); S. $785\left(114^{\text {th }}\right)$ : FRAC Act, GOVTRACK.US, https://www.govtrack.us/congress /bills/114/s785 (last visited Nov. 26, 2015) (indicating a 0\% chance of S. 785 being enacted).

12342 U.S.C. §§ 6901-92 (2012).

12442 U.S.C. § 6902(a) (2012).

125 See 42 U.S.C. § 6921 (2012); see also Reser \& Ritter, supra note 104, at 32.

126 See 42 U.S.C. §§ 6901-92; see also Reser \& Ritter, supra note 104, at 32. 
characteristics" such as ignitability, corrosivity, reactivity, or toxicity; ${ }^{127}$ (2) A waste may be considered "acutely toxic" based on studies showing that even low doses would be fatal to humans; ; ${ }^{128}$ (3) A waste contains certain toxic constituents and is capable of posing substantial harm if managed improperly. ${ }^{129}$ Despite hydrofracking's use of over 600 known chemicals, ${ }^{130}$ many of which would easily be considered "hazardous" under the test employed by RCRA, wastes associated with exploration and production of oil and natural gas through hydrofracking have been expressly exempted by the Act. ${ }^{131}$ EPA classifies these wastes as "special wastes." ${ }^{332}$ These "special wastes" include: produced water, drilling fluids, stimulation fluids, as well as pit sludges and contaminated bottoms from storage or disposal of exempt wastes. ${ }^{133}$ The decision to exempt these wastes under RCRA does not indicate a conclusion that these wastes are not hazardous. ${ }^{134}$ EPA has openly admitted that many of these wastes do pose a hazard to human health and the environment if not properly managed. ${ }^{135}$

\section{B. State Regulation of Hydraulic Fracturing}

Because of the many exemptions to federal legislation, state regulation is the primary mechanism for regulation of hydrofracking. ${ }^{136}$

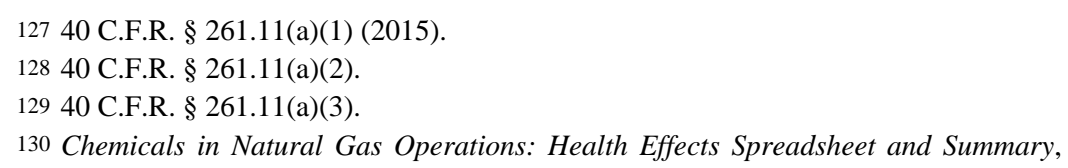
THE ENDOCRINE DISRUPTION EXCHANGE (2011), http://endocrinedisruption.org /chemicals-in-natural-gas-operations/chemicals (click on link to "Spreadsheet of products, chemicals and their health effects, click on the "Chemicals" tab in the spreadsheet (Excel)").

13142 U.S.C. § 6921(b)(2)-(3) (2012). Note that only wastes associated with exploration and production of oil and natural gas are exempt under RCRA. There are other aspects of hydrofracking that are in fact subject to RCRA regulation. See U.S. ENVTL. PROT. AGENCY, EXEMPTION OF OIL AND GAS EXPLORATION AND PRODUCTION WASTES FROM FEDERAL HAZARDOUS WASTE REGULATIONS 11 (2002), http://www3.epa.gov/epawaste/nonhaz /industrial/special/oil/oil-gas.pdf.

132 U.S. ENVTL. PROT. AgENCY, supra note 131, at 5.

133 Id. at 10.

134 See id.

$135 \mathrm{Id}$. at 5. EPA recognizes the responsibility to manage these risks, however, it is a priority for EPA to foster development of America's shale gas resources, citing its "important economic, energy security, and environmental benefits." Natural Gas Extraction-Hydraulic Fracturing, U.S. EPA, http://www2.epa.gov/hydraulicfracturing (last updated Oct. 23, 2015).

136 See Reser \& Ritter, supra note 104; Francis Gradijan, State Regulations, Litigation, and Hydraulic Fracturing, 7 ENVT'L \& ENERGY L. \& POL’Y J. 47, 62 (2012); Wiseman, 
State regulation of hydrofracking is, in many ways, lacking and insubstantial, creating a risk for individuals who live in the vicinity of hydrofracking operations.

States vary greatly in the way they approach regulating hydrofracking. ${ }^{137}$ Hydrofracking is currently conducted in around thirty states. ${ }^{138}$ There are dozens of elements to the hydrofracking process that can be reached by state regulation. ${ }^{139}$ States differ in how much of the hydrofracking process they choose to regulate and the methods they choose in achieving this goal. ${ }^{140}$ Two critical components of hydrofracking regulation include disclosure rules for toxic chemicals and regulations for wastewater disposal. Because of the toxic nature of frac fluid and hydrofracking wastewater, it is imperative that states employ regulations to manage these hazardous products and ensure public safety. A discussion of how states treat both of these subjects will illustrate the gaps that remain in state regulation of hydrofracking.

The disclosure of chemical compositions used in hydrofracking is an essential prerequisite to the evaluation of potential adverse environmental and public health consequences. It has been argued that "given the extremely low costs imposed by disclosure requirements, no credible policy justification has been advanced for limiting the scope of disclosure rules." ${ }^{141}$ However, of the states where hydrofracking is prevalent, nearly one-third have no disclosure rule to cover this activity at all. ${ }^{142}$ In the remaining two-thirds of states, disclosure requirements

Untested Waters: The Rise of Hydraulic Fracturing in Oil and Gas Production and the Need to Revisit Regulation, supra note 21, at 157.

137 See RICHARDSON ET AL., supra note 15.

$138 \mathrm{Id}$. at 2 . In addition to the 27 states where fracking is already occurring, there are at least 4 other states that display an interest in fracking or that have significant shale reserves, indicating a potential future in fracking. Michael Burger, The (Re)Federalization of Fracking Regulation, 2013 MicH. ST. L. REV. 1483, 1485 (2013). McFeeley, supra note 7, at 850 (estimating the number of states conducting hydraulic fracturing at thirty-two) (noting that "[b]ecause federal disclosure requirements do not exist, the number of states with fracking is impossible to determine with certainty").

139 RICHARDSON ET AL., supra note 15, at 13.

$140 \mathrm{Id}$. In regards to the number of elements regulated, New York, West Virginia, Colorado, Michigan, Pennsylvania, New Mexico, Alabama, Kansas, Louisiana, Ohio, Texas, and Wyoming are at the top, with the greatest quantity of regulation. States with the least number of elements regulated include Indiana, Mississippi, South Dakota, Tennessee, California, and Virginia. The remainder of the 27 states comprise the middle portion of the spectrum.

141 McFeeley, supra note 7, at 860.

142 Id. at 850. 
vary widely in scope and substance. ${ }^{143}$ For example, in those states with disclosure rules, sixteen states require disclosure of toxic chemicals for all hydraulic fracturing, ${ }^{144}$ whereas six caveat the disclosure based on certain minimum requirements. ${ }^{145}$

The public accessibly of disclosed chemicals also varies. ${ }^{146}$ Ten states rely on a website called FracFocus.org as the primary or sole means of disclosure by hydrofracking operators. ${ }^{147}$ Another five states incorporate use of FracFocus into their reporting requirements. ${ }^{148}$ Essentially, these states require hydrofracking operators to disclose the chemicals used in their operations directly to FracFocus, which is then made publicly available on FracFocus' website. ${ }^{149}$ The issue with this manner of disclosure is that the responsibility for accuracy, timeliness, and completion is placed in the hands of a private party. ${ }^{150}$ In fact, FracFocus even states that it "'assume[s] no responsibility for the timeliness, deletion, misdelivery, or failure to store any' information." ${ }^{151}$

Another crucial component of disclosure law is the requirement to notify local homeowners before hydrofracking is performed in order to give potentially affected individuals time to perform baseline testing of their wells. ${ }^{152}$ Baseline testing done prior to any hydrofracking is essential for establishing data on the quality of well in the event that wells become contaminated as a result of nearby operations. ${ }^{153}$ Without

143 Id. at 859.

144 Id. at 850 (the term "all hydraulic fracturing” meaning no exemptions or exceptions. States requiring disclosure include Alabama, Arkansas, California, Colorado, Indiana, Louisiana, Mississippi, Montana, New Mexico, North Dakota, Ohio, Oklahoma, South Dakota, Texas, Uah, and Wyoming).

145 Id. (these states include Illinois, Kansas, Michigan, Pennsylvania, Tennessee, and West Virginia). For example, West Virginia does not require disclosure for fracking jobs that disturb less than three acres of surface. $I d$.

146 Id. at 864-70.

147 Id. at 863 (these states include Colorado, Kansas, Montana, North Dakota, Ohio, Oklahoma, South Dakota, Tennessee, Texas, and Utah).

148 Id. at 862-63 (these states include Alabama, Louisiana, Mississippi, Pennsylvania, and West Virginia). States that require disclosures directly to the state include Arkansas, California, Illinois, Indiana, Michigan, New Mexico, and Wyoming. Id.

149 Id. at 863.

150 Id.

151 Id. (citing Website Terms and Conditions of Use, FRACFOCUS.ORG, http://fracfocus .org/terms-of-use (last visited Oct. 28, 2015)).

152 McFeeley, supra note 7, at 870.

153 Id. 
this evidence, it is difficult to establish causation, and thus, difficult for the affected individual to sue for damages against the hydrofracking operator. ${ }^{154}$ Only California and Colorado require notification of fracking to be made to nearby homeowners and tenants. ${ }^{155}$ Illinois and West Virginia require notification to the landlord only. ${ }^{156}$ The remaining eighteen states do not require any notification at all. ${ }^{157}$

Regulation of wastewater is another important element of hydrofracking regulation, as the onsite maintenance and disposal of wastewater is essential to preventing water contamination and associated health hazards. ${ }^{158}$ Federal water quality laws often address disposal of wastewater, whereas the state laws primarily address onsite storage and handling of wastewater. ${ }^{159}$ State regulation of onsite storage and handling of wastewater varies in how wastewater is required to be stored and what types of wastewater are allowed to be stored. Wastewater is stored, primarily, in either open pits or tanks. ${ }^{160}$ Additionally, drilling muds and flowback water are often treated differently due to the fact that flowback water tends to have higher concentrations of chemicals. ${ }^{161}$ States can be categorized into four different groups depending on the way they treat these distinctions. ${ }^{162}$ To begin with, no state requires storage of all fluids in tanks. ${ }^{163}$ The first group, comprising ten states, requires storage in tanks of at least some fluids. ${ }^{164}$ The second group, comprising sixteen states, does not require tank storage for any type of fluid, ${ }^{165}$ thus all fluid may be stored in open pits if desired. ${ }^{166}$ The third group, comprising three states,

\footnotetext{
154 Id.

155 Id. In Colorado, operators must only notify landlords and tenants within 500 feet of the well, while California only requires notice to landlords and tenants within 1500 feet of the well. Id. at n.128.

156 Id. at 870.

157 Id.

158 See supra notes 51-66.

159 Michael N. Mills \& Robin B. Seifried, What is Fracking Wastewater and How Should We Manage It?, 28 NAT. RESOURCES \& ENV'T 3, 12 (2014).

160 RICHARDSON ET AL., supra note 15, at 46.

161 Id.

162 Id. at $46-48$.

163 Id. at 46.

164 Id. at 47 map 12 (these states include Minnesota, North Dakota, New Mexico, Oklahoma, Arkansas, Louisiana, Mississippi, North Carolina, Michigan, and New York).

165 Id. (these states include California, Wyoming, Utah, Colorado, South Dakota, Texas, Ilinois, Indiana, Kentucky, Tennessee, Alabama, Gerogia, Virginia, West Virginia, Pennsylvania, and Maryland).

166 Id. (these states include Kansas, Nebraska, and Ohio).
} 
requires permit applications for fluid storage. ${ }^{167}$ The remaining two states have no regulation mentioning wastewater storage whatsoever. ${ }^{168}$

Some states have chosen to place a moratorium on hydrofracking or ban hydrofracking all together. In August 2011, New York became the first state to place a temporary moratorium on natural gas exploration. This moratorium was intended "to give the State adequate time to assess the risks of hydraulic fracturing and move forward in a responsible manner."169 Two other states, New Jersey and North Carolina, followed suit, stating a need for time to complete "further study on the impact of fracking on human health and the environment and to implement corresponding regulations governing the practice in more detail as necessary." ${ }^{170}$ In December 2014, New York Governor Andrew Cuomo's administration announced its decision to ban hydraulic fracturing citing "significant public health risks." 171 In addition to New York, Vermont has also chosen to ban hydrofracking. ${ }^{172}$

In the thirty states that do allow hydrofracking, state regulation may not adequately protect individuals from health and property related damages. Therefore, to ensure protection for local citizens, municipalities may be able to use their home rule powers to implement rules that work best for their particular locality and more adequately insulate their residents from the hazards of hydrofracking.

\section{IV \\ SUGGESTED STRATEGIES FOR MUNICIPALITIES}

Some municipalities have been successful in restricting and or banning hydrofracking within their borders using their home rule powers. As a primer, it is important to clarify that a municipality is only authorized to utilize their home rule powers within certain

167 Id. (these states include New Jersey and Vermont).

168 Id.

169 Joshua P. Dennis, The Emergence of Natural Gas and the Need for Cooperative Federalism to Address a Big "Fracking” Problem, 4 SAN DiEgo J. ClimATE \& ENERGY L. 253, 268-69 (2012-2013) (citing Mireya Navarro, N.Y. Senate Approves Fracking Moratorium, N.Y. TimES (Aug. 4, 2010, 1:23 PM), http://green.blogs.nytimes.com/2010 /08/04/n-y-senate-approves-fracking-moratorium/).

170 Mills \& Seifried, supra note 159, at 12.

171 Orden \& Cook, supra note 3.

172 Mills \& Seifried, supra note 159, at 12. 
jurisdictional boundaries. ${ }^{173}$ All municipalities must look to their state constitutions or state statutes to determine the extent of their home rule powers. ${ }^{174}$ In some cases, state law may preempt a municipality from enacting certain ordinances. If the state legislature has enacted a uniform state law, the municipality will not be permitted to enact an ordinance that conflicts with that law. ${ }^{175}$

Thus, a municipality may not always be permitted to exercise their home rule powers to the fullest extent in restricting or banning hydrofracking within their borders. ${ }^{176}$ However, several municipalities have successfully accomplished this goal and it may serve as a guide to other municipalities who wish to follow suit.

\section{A. Legal Precedent for the Power of Municipalities to Use Home Rule to Restrict Hydraulic Fracturing Operations}

The following New York cases serve as an illustration of a municipality's success in using their home rule powers to ban hydrofracking. In Anschutz Exploration Corp. v. Town of Dryden ${ }^{177}$ and Cooperstown Holstein Corp. v. Town of Middlefield, ${ }^{178}$ the court addressed whether a municipality can exercise its police powers to enact local zoning ordinances that ban the use of land for hydrofracking. ${ }^{179}$ In both cases, the plaintiffs (hydrofracking operators) claimed that a state law, New York's Environmental Conservation Law ("ECL"), preempted a municipality from enacting this type of ordinance. ${ }^{180}$ ECL $\S 23-0303(2)$ states: "The provisions of [Mineral Resources Article 23 of the ECL] shall supersede all local laws or

173 JAMES JAY BROWN, A Brief Guide to Understanding Zoning and Land Use Planning, THE FlA. BAR 1994, at 7 (Fla. Envtl. \& Land Use Law, Main Handbook ELUII FL-CLE 11, 1994).

174 Heim, supra note 11, at 28.

175 See id. at 31.

176 See Ne. Nat. Energy, L.L.C. v. City of Morgantown, Civ. Act. No. 11-C-411, slip op. at 10, 2011 WL 3584376 (W. Va. Cir. Ct. Aug. 12, 2011) (holding that the City of Morgantown, West Virginia's ban on hydrofracking was inconsistent with West Virginia state legislation). For an in depth discussion of the difference between home rule powers throughout the United States, see Jarit C. Polley, Uncertainty for the Energy Industry: A Fractured Look at Home Rule, 34 ENERGY L.J. 261 (2013).

177 Anschutz Expl. Corp. v. Town of Dryden, 940 N.Y.S.2d 458 (N.Y. Sup. Ct. 2012).

178 Cooperstown Holstein Corp. v. Town of Middlefield, 943 N.Y.S.2d 722 (N.Y. Sup. Ct. 2012).

179 Dryden, 940 N.Y.S.2d 458; Middlefield, 943 N.Y.S.2d 722; Charles Gottlieb, Regulating Natural Gas Development Through Local Planning and Land Use Controls, 12 NO. 6 NEW YORK ZONING LAW AND PRACTICE REPORT 1, 2 (2012).

180 Dryden, 940 N.Y.S.2d 458; Middlefield, 943 N.Y.S.2d 722; Gottlieb, supra note 179. 
ordinances relating to the regulation of the oil, gas and solution mining industries."

In both cases, the court held in favor of the municipality, finding that New York state law did not preempt the municipality in enacting zoning ordinances that banned hydrofracking. ${ }^{181}$ The Dryden court found a distinction between "ordinances that regulate property uses and ordinances that regulate mining activities." 182 Essentially, the municipality is preempted from regulating the "how" of hydrofracking, but not the "where." 183 The court also noted, that incidental effects of zoning ordinances and land use laws upon the extractive mining industry does not make the ordinance preempted by state law. ${ }^{184}$ Similarly, the Middlefield court held that "preemption does not apply to local regulations addressing land use which may, at most, 'incidentally' impact upon the 'activities' of the industry of oil, gas and solution drilling or mining." 185

Notably, the Dryden court recognized the public interest in insulating individuals from the risks posed by hydrofracking by quoting the court in Matter of Gernatt, which stated that:

A municipality is not obliged to permit the exploitation of any and all natural resources within the town as a permitted use if limiting that use is a reasonable exercise of its police powers to prevent damage to the rights of others and to promote the interests of the community as a whole. ${ }^{186}$

Municipalities in other states have also been successful in banning or restricting hydrofracking. In Trail Enterprises, Inc. v. City of Houston, the Texas court upheld a Houston ordinance prohibiting oil and gas drilling within its watershed. ${ }^{187}$ In Tri-Power Resources, Inc. $v$. City of Carlyle, an Illinois court upheld the city's zoning ordinance prohibiting the drilling of an oil or gas well within city limits. ${ }^{188}$ Finally, in Huntley \& Huntley $v$. Borough of Oakmont, the Pennsylvania Supreme Court upheld a zoning ordinance restricting

181 Dryden, 940 N.Y.S.2d 458; Middlefield, 943 N.Y.S.2d 722; Gottlieb, supra note 179.

182 Dryden, 940 N.Y.S.2d at 460.

183 Gottlieb, supra note 179, at 5.

184 Dryden, 940 N.Y.S.2d at 460.

185 Middlefield, 943 N.Y.S.2d 722, 729.

186 Gernatt Asphalt Products, Inc. v. Town of Sardinia, 664 N.E.2d 1226, 1235 (N.Y. 1996).

187 Trail Enterprises, Inc. v. City of Houston, 957 S.W.2d 625, 628 (Tex. App. 1997).

188 Tri-Power Res., Inc. v. City of Carlyle, 967 N.E.2d 811 (Ill. App. Ct. 2012). 
hydrofracking within a classified residential district. ${ }^{189}$ Thus, there is ample legal precedent for municipalities to utilize their home rule powers to enact zoning ordinances and land use laws that may restrict or even ban hydrofracking.

\section{B. Suggested Zoning Ordinances and Land Use Laws that Will Limit the Negative Impacts of Hydraulic Fracturing upon Local Residents}

Assuming that a municipality has the ability to utilize their home rule powers to the fullest extent, there are various strategies that a municipality may consider in order to protect its residents from the hazards of hydrofracking.

Each municipality may have different interests in allowing or restricting hydrofracking. It is up to the municipality to determine how far they want to go in limiting hydrofracking within their borders. The following suggestions are merely a starting point; a sample of possible general strategies that municipalities may employ to mitigate the common negative impacts of hydrofracking. These suggestions will be discussed in order from least restrictive to most restrictive.

\section{Enact or Modify Local Comprehensive Plans}

All municipalities could benefit from enacting or updating their comprehensive plans. Comprehensive plans vary from state to state, and from municipality to municipality. ${ }^{190}$ Nevertheless, in general, the local comprehensive plan is a foundational document for land use planning which "directs the use and development of property in a municipality." 191 Comprehensive plans generally divide the municipality into districts according to present and potential uses. ${ }^{192}$

All zoning ordinances are to be implemented "in accordance with" the comprehensive plan. ${ }^{193}$ Therefore, in thinking about the ways that a municipality may desire to limit hydrofracking within its borders, it

189 Huntley \& Huntley, Inc. v. Borough Council of the Borough of Oakmont, 964 A.2d 855 (Рa. 2009).

190 See Mark S. Dennison, Annotation, Zoning Action Not in Accordance with a Comprehensive Plan, 37 AM. JUR. PROOF OF FACTS 3d 383 (2015).

191 Brown, supra note 173, at 7 (citing Nowicki v. Planning \& Zoning Board of Town of Milford, 172 A.2d 386 (Conn. 1961)).

192 Dennison, supra note 190 (citing Brackett v. Des Moines, 67 N.W.2d 542, 546 (1954)).

193 Id. (noting that judicial interpretations regarding this requirement have varied). 
is essential that the local comprehensive plan provide a foundation for this power.

The comprehensive plan is important because it plays a significant role in deciding whether to approve a proposed permit for new hydrofracking operations. ${ }^{194}$ If the proposed permit would be inconsistent with the locality's comprehensive plan, the state can reject the permit, request modifications, or require certain mitigation techniques to be employed. ${ }^{195}$

This was the case in Huntley \& Huntley v. Borough Council of Borough of Oakmont, where the Pennsylvania Supreme Court upheld a zoning ordinance restricting hydrofracking within a classified residential district. ${ }^{196}$ In Huntley, an engineering company sought to extract natural gas from two parcels of land located within a zoning district designated as an R-1 (single-family) residential district. ${ }^{197}$ The engineering company was denied a permit to conduct operations on this land. ${ }^{198}$ The zoning ordinance indicated that in R-1 residential districts, commercial operations were strictly prohibited, but the "extraction of minerals" would be allowed as a conditional use. ${ }^{199}$ The engineering company presented two arguments: (1) natural gas falls under the definition of "mineral" contemplated by the ordinance; and (2) in the alternative, the Borough was preempted from restricting the location of natural gas extraction operations by the Pennsylvania Oil and Gas Act. ${ }^{200}$

The court analyzed the language of the Pennsylvania Oil and Gas Act and ultimately determined that "natural gas" did not fall under the definition of "mineral" as contemplated by the ordinance, and that the Borough's ordinance was not preempted by the Act. ${ }^{201}$ Notably, in interpreting the Borough's ordinance, the court looked to the Borough's goals and purposes underlying their decision to enact the ordinance in question. ${ }^{202}$ Relying in part on the Colorado Supreme

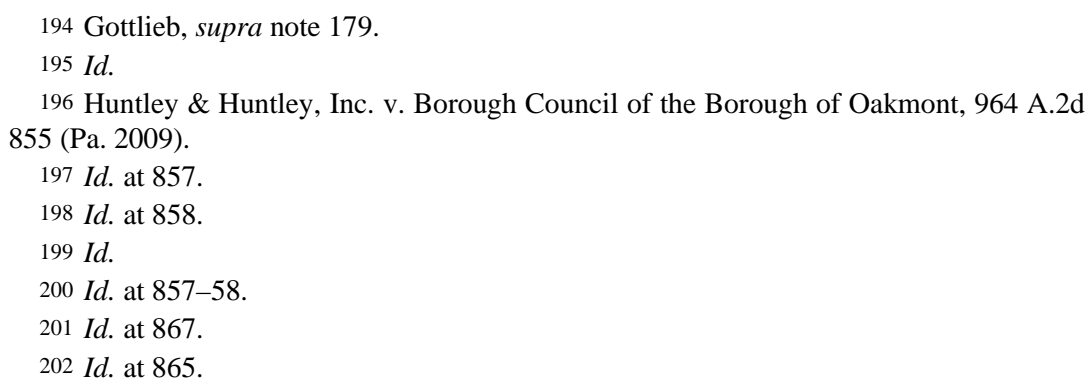


Court's decision in Board of County Commissioners of La Plata County v. Bowen/Edwards Associations, the Pennsylvania Supreme Court emphasized that "authorization of local zoning laws is provided in recognition of the unique expertise of municipal governing bodies to designate where different uses should be permitted in a manner that accounts for the community's development objectives, its character, and the "suitabilities and special nature of particular parts of the community.",203

In sum, municipalities should take advantage, to the extent they are capable, of enacting or modifying comprehensive plans to designate where hydrofracking can or cannot be conducted.

\section{Enact Zoning Ordinances Increasing the Required Distance of Hydraulic Fracturing Operations from High Risk Areas}

Another effective strategy that localities may employ is to enact zoning ordinances that restrict hydrofracking within a certain distance of high-risk areas that a municipality may determine requires enhanced protection. These areas may include: residences, schools, churches, or popular locations for recreation and tourism. Due to public health and property related damages, municipalities have an incentive to restrict hydrofracking within areas where individuals may be placed at risk.

An example of this type of ordinance is a Fayette County, Pennsylvania zoning ordinance that prohibits an oil or gas well "within two-hundred (200) feet of a residential dwelling or fifty-(50) feet from any property line or right-of-way." ${ }^{204}$ In Penneco Oil Company, Inc. v. County of Fayette, an oil company challenged this zoning ordinance, claiming that Pennsylvania's Oil and Gas Act preempted Fayette County from regulating oil and gas drilling in this manner. ${ }^{205}$ The court cited Huntley ${ }^{206}$ as precedent, holding that the Fayette County Zoning Ordinance was a permissible regulation that identifies "which uses are permitted in different areas of the locality."207 The court also pointed to Fayette County's underlying objectives in enacting the ordinance, being to "preserv[e] the character of residential neighborhoods . . . and encourag[e] beneficial and compatible land uses."208

\footnotetext{
203 Id. at 866 (quoting 53 P.S. § 10603 (2008)).

204 Fayette Cty., Pa., Zoning Ordinance § 1000-851(B) (2006).

205 See Penneco Oil Co., Inc. v. Cty. of Fayette, 4 A.3d 722 (Pa. Commw. Ct. 2010).

206 Borough of Oakmont, 964 A.2d 855.

207 Penneco Oil Co., 4 A.3d at 733.

208 Id. at 732.
} 


\section{Ban Hydraulic Fracturing}

Finally, a municipality may be able to ban hydrofracking in its entirety. Areas with high population densities, a strong tourism industry, or a significant amount of previous environmental pollution may find this to be a desirable choice. Cities such as Dryden, New York, Middlefield, New York, Houston, Texas, and Carlyle, Illinois, have successfully banned hydrofracking within their borders. ${ }^{209}$

Of course, the ability to implement a zoning ordinance restricting hydrofracking to this extent will ultimately rest upon the municipality's home rule powers under their respective state statutes. However, the success of some municipalities in banning hydrofracking may serve as a guide to others who wish to do the same.

\section{CONCLUSION}

Although hydrofracking may provide a number of benefits, such as domestic energy sources and financial gain, it comes at a high price for many individuals who live within the vicinity of hydrofracking operations. It is inequitable for these individuals to bear this burden by risking health and property damages.

The current regulatory regime for hydrofracking is inadequate at both the state and federal level, heightening the need for better protection by municipalities. Using their home rule powers, municipalities may be able insulate their residents from health and property damages, by restricting or even banning hydrofracking within their borders.

209 Anschutz Expl. Corp. v. Town of Dryden, 940 N.Y.S.2d at 460 (N.Y. Sup. Ct. 2012); Cooperstown Holstein Corp. v. Town of Middlefield, 943 N.Y.S.2d 722 (N.Y. Sup. Ct. 2012); Trail Enters., Inc. v. City of Houston, 957 S.W.2d 625, 628 (Tex. App. 1997); TriPower Res., Inc. v. City of Carlyle, 967 N.E.2d 811 (Ill. App. Ct. 2012). 
